\title{
Analisis Rasio Keuangan Pada Financial Distress Perusahaan Retail Yang Terdaftar Di Bei $(2016-2019)$
}

\author{
Lutfianan Nur Azizah, Arisyahidin \\ Magister Manajemen, Universitas Islam Kadiri \\ e-mail: lutfianannur@gmail.com
}

\begin{abstract}
Abstrack
This study aims to determine the effect of profitability, liquidity, leverage, and activity in predicting financial distress conditions in retail companies on the Indonesia Stock Exchange (IDX) for the period 2016-2019. The sampling technique used was purposive sampling with a number of selected samples of 18 companies. The number of samples used was as many as 7 companies in the category of experiencing financial distress and 11 companies in the category did not experience financial distress. The results of the study using logistic regression show that profitability measured by the Return on Investment (ROI) has a negative effect on financial distress. Liquidity as measured by Current Ratio (CR) has a negative effect on financial distress. Leverage measured by Debt to Equity Ratio (DER) has a negative effect on financial distress. Activity measured by Fixed Assetss Turnover (FAT) not has a effect on financial distress.
\end{abstract}

Keywords: financial distress, profitability, liquidity, leverage, and activity

\section{Latar Belakang Teoritis}

Dewasa ini, perkembangan ekonomi di Indonesia ditahun 2020 melemah dibanding pertumbuhan ekonomi ditahun 2019. Hal ini dibuktikan dengan data dari Badan Statistika Nasional yang mana ekonomi di tahun 2020 minus sebesar $2,07 \%$ dibandingkan dengan pertumbuhan ekonomi di tahun 2019. Melemahnya ekonomi Indonesia merupakan imbas dari krisis global yang terjadi saat ini akibat pandemi yang berkepanjangan. Salah satu dampak yang paling dirasakan saat ini adalah kesulitan yang sangat besar terhadap perekonomian dimana banyak sekali pengusaha yang dengan terpaksa menutup usahanya dan memberhentikan pegawainya, tidak ada pilihan lain yang bisa diambil karena usahanya tidak bisa beroperasi sebagaimana biasanya.

Keadaan ekonomi yang sulit seperti saat ini yang berimbas pada usaha kecil maupun besar akan memaksa pelaku usaha untuk berfikir lebih keras supaya usahanya tidak mengalami kebangkrutan. Kebangkrutan suatu perusahaan dapat dilihat dan diamati dari laporan keuangannya. Laporan keuangan merupakan informasi yang menyediakan tentang posisi keuangan, kinerja keuangan, dan laporan arus kas suatu perusahaan yang bermanfaat dalam pengambilan keputusan ekonomi bagi pengguna (Rudianto, 2012:20). Laporan keuangan yang disusun suatu perusahaan merupakan sumber informasi utama yang digunakan untuk mengetahui posisi keuangan suatu perusahaan. Menurut kasmir (2016:11) laporan keuangan dibuat dengan tujuan untuk memberikan informasi tentang jenis dan jumlah aktiva, kewajiban, modal, pendapatan, biaya, perubahan yang terjadi di perusahaan saat ini, kinerja manajemen, serta catatan-catatan lain tentang perusahaan yang terjadi saat ini. Laporan keuangan sangat berguna bagi stakeholder sebagai bahan pertimbangan untuk mendukung dalam pengambilan keputusan yang tepat.

Meskipun laporan keuangan menyajikan data yang lengkap, tetapi tidak semua orang mampu membaca laporan keuangan. Oleh sebab itu, laporan keuangan harus dikonversi menjadi informasi yang lebih bermanfaat dan berguna untuk pengambilan keputusan yang lebih ekonomis. Salah satu bentuk pelaksanaan dari pembuktian manfaat laporan keuangan adalah dengan cara menganalisa melalui rasio-rasio keuangan. Menurut Munawwir (2010:32) analisis laporan keuangan terdiri atas mempelajari dan menelaah antara hubungan serta tendensi dalam hal kecenderungan untuk menentukan posisi keuangan, hasil operasi dan perkembangan perusahaan yang bersangkutan. Analisa laporan keuangan berguna untuk memprediksi kinerja keuangan dari kebangkrutan dan financial distress.

$$
\text { Financial Distress merupakan }
$$

penurunan kondisi keuangan yang dialami dalam perusahaan sebelum mengalami 
kebangkrutan (Dwijayanti, 2010:191). Kondisi ini dapat diukur melalui Altman ZScore yang merupakan salah satu model prediksi kebangkrutan pada sebuah perusahaan. Model prediksi kebangkrutan ini dipilih karena memiliki akurasi yang baik dalam memprediksi kebangkrutan dengan nilai 95\% (Altman, 1968:609). Dimana Altman Z-Score menggunakan empat rasio keuangan untuk perusahaan ritel yaitu Modal kerja terhadap Total aset, Laba ditahan terhadap Total aset, Laba sebelum bunga dan pajak terhadap Total aset, dan Nilai pasar ekuitas terhadap Nilai buku total hutang.

Rasio profitabilitas merupakan rasio yang dipergunakan untuk mengukur kemampuan perusahaan dalam menghasilkan keuntungan yang didasarkan pada tingkat penjualan, aset, dan modal saham tertentu yang ada pada perusahaan (Hanafi, 2015:42). Rasio ini dapat diproksikan dengan menggunakan Return On Investment (ROI). Hasil penelitian ini telah dilakukan oleh Wayan (2019), menyatakan bahwa rasio profitabilitas berpengaruh negatif signifikan dalam memprediksi kondisi financial distress, sedangkan penelitian yang dilakukan oleh Wulandari (2017) bahwa rasio profitabilitas tidak memiliki pengaruh yang signifikan dalam memprediksi kondisi financial distress sebuah perusahaan. Berdasarkan uraian di atas, maka hipotesis yang peneliti ajukan adalah:

$\mathrm{H}_{1}$ Rasio profitabilitas berpengaruh negatif terhadap financial distress.

Rasio likuiditas merupakan rasio yang digunakan untuk mengukur kemampuan perusahaan dalam memenuhi kewajiban jangka pendek (Hanafi,2015:42). Apabila perusahaan mampu melunasi kewajiban pendeknya dengan baik maka potensi terjadinya kondisi financial ditress juga semakin kecil (Septiani dan Dana, 2019). Hasil penelitian ini telah dilakukan oleh Septiana dan Dana (2019), menyatakan bahwa likuiditas berpengaruh negatif signifikan dalam memprediksi kondisi financial distress, sedangkan penelitian yang dilakukan oleh Wonokinasih (2018) tidak berpengaruh dalam memprediksi kondisi financial distress. Berdasarkan uraian di atas, maka peneliti mengajukan hipotesis,
$\mathrm{H}_{2}$ Rasio likuiditas berpengaruh negatif terhadap financial distress.

Rasio leverage digunakan untuk mengukur kemampuan perusahaan hingga sejauh mana perusahaan mampu melaksanakan kewajiban jangka panjangnya (Hanafi, 2015). Pada penelitian ini di proyeksikan dengan Debt To Assets Ratio (DAR) karena untuk mengetahui perbandingan antara total utang dengan total aset. Logika yang dapat digunakan di sini yaitu apabila pembiayaan usaha perusahaan lebih banyak menggunakan utang, resiko yang akan terjadi adalah kesulitan pembayaran utang di masa mendatang karena rasio hutang yang mungkin semakin besar (Nukmaningtyas dan Worokinasih : 2018). Hasil penelitian ini telah dilakukan oleh Nurrachma (2019) menyatakan bahwa rasio Leverage berpengaruh positif signifikan terhadap Financial distress, sedangkan hasil penelitian dari Widhiari dan Nukmanigtyas (2018), menyatakan bahwa rasio Leverage tidak berpengaruh terhadap financial distress. Berdasarkan uraian di atas, maka hipotesis yang peneliti ajukan adalah:

$\mathrm{H}_{3}$ Rasio leverage berpengaruh positif terhadap financial distress

Rasio aktivitas yaitu rasio yang digunakan untuk mengukur efektivitas perusahaan guna mengoptimalkan sumber daya yang dimiliki perusahaan. Rasio ini dapat diukur dengan Fixed Assets Turnover (FAT), pengukuran ini digunakan untuk mengetahui kemampuan perusahaan dalam menggunakan asetnya untuk menghasilkan penjualan yang dapat menambah laba perusahaan. Semakin efektif perusahaan dalam menggunakan asetnya untuk meningkatkan penjualan, maka diharapkan perusahaan mendapatkan keuntungan yang semakin besar. Hasil penelitian ini telah dilakukan oleh Wayan Agustini (2019) menyatakan bahwa rasio aktivitas berpengaruh negatif signifikan dalam memprediksi kondisi financial distress, sedangkan penelitian yang dilakukan oleh Wulandari (2017) menyatakan bahwa rasio aktivitas tidak berpengaruh terhadap financial distress. Berdasarkan uraian di atas, maka hipotesis yang peneliti ajukan adalah,

$\mathrm{H}_{4}$ Rasio aktivitas berpengaruh negatif terhadap financial distress. 
Objek yang digunakan dalam penelitian ini adalah perusahaan retail yang terdaftar di Bursa Efek Indonesia tahun 2016-2019. Alasan penulis memilih perusahaan retail karena adanya fenomena yang telah terjadi saat ini. Sektor bisnis retail merupakan bisnis yang sangat rawan gulung tikar akibat fenomena yang terjadi seperti saat ini yaitu COVID-19. Peneliti mencoba untuk memberikan prediksi mengenai kondisi-kondisi yang membuat perusahaan retail rawan terhadap ancaman pandemi seperti saat ini, sehingga peneliti mengambil sampel dalam rentang sebelum pandemi COVID-19 dengan alasan kerawanan tersebut. Jika permintaan pasar menurun, pengusaha retail tetap harus dihadapkan pada pembayaran komponen - komponen biaya tetap / fixed cost yang mana harus dibayar tanpa memandang keadaan pasar. Jika biaya ini tidak bisa dibayar karena pendapatan menurun drastis, maka akan muncul fenomena-fenomena yang bisa dikatakan sebagai gejala kebangkrutan seperti pemotongan gaji karyawan yang nantinya akan berimbas pada menurunnya daya beli masyarakat.

\section{Metode Penelitian \\ Lokasi Penelitian}

Penelitian ini dilakukan pada perusahaan yang terdaftar di Bursa Efek Indonesia (BEI), dimana peneliti menggunakan data berupa laporan keuangan perusahaan retail pada sektor perdagangan eceran tahun 20162019 yang diakses melalui website Bursa Efek Indonesia (BEI) yaitu www.idx.co.id.

\section{Definisi Operasional Variabel}

\section{Rasio Profitabilitas}

Rasio profitabilitas digunakan untuk mengukur kemampuan perusahaan untuk menghasilkan keuntungan yang didasarkan pada tingkat penjualan, aset, dan modal saham tertentu yang ada (Hanafi, 2015:42).

2 Rasio Likuiditas

Rasio likuiditas merupakan rasio yang digunakan dalam mengukur kemampuan perusahaan dalam memenuhi kewajiban jangka pendek (Hanafi, 2015:37).

3 Rasio Leverage
Rasio rasio leverage adalah rasio yang digunakan untuk mengukur kemampuan perusahaan menggunakan asetnya dalam membiayai utang jangka panjangnya (Hanafi,2015:40).

4 Rasio Aktivitas

Rasio aktivitas adalah rasio yang digunaka untuk mengetahui seberapa besar efisien perusahaan dalam menggunakan aset yang dimilikinya (Hanafi, 2015:38).

5 Financial Distress

Menurut (Platt dan Platt dalam Tri Wulandari (2017:18) Financial distress merupakan keadaan suatu perusahaan dimana mengalami kesulitan keuangan sebelum benar-benar terjadi kebangkrutan atau likuidasi. Financial distress dapat mencerminkan adanya permasalahan dengan likuidasi yang tidak dapat diatasi tanpa harus melakukan perubahan atau restrukturisasi perusahaan (Munawwir, 2010:291). Financial distress merupakan variabel dependen yang menggunakan variabel dummy. Varibel ini menggunakan kategori yang dinyatakan dengan angka 1 jika perusahaan mengalami financial distress dan angka 0 jika perusahaan tidak mengalami financial distress (Hanafi, 2015:180).

\section{Teknik Pengambilan Sampel}

Teknik pengambilan sampel dalam penelitian ini adalah purposive sampling yang berarti sampel dipilih dengan pertimbangan tertentu agar dapat menghasilkan data yang sesuai dengan tujuan penelitian (Sugiyono, 2017:85). Kriteria-kriteria yang digunakan dalam pengambilan sampel sebagai berikut:

1. Perusahaan Retail yang terdaftar di Bursa Efek Indonesia (BEI) pada tahun 2016-2019.

2. Perusahaan yang memiliki laporan keuangan tahun 2016-2019.

3. Perusahaan yang menyampaikan data secara lengkap laporan keuangan selama periode penelitian 2016-2019 di Bursa Efek Indonesia (BEI) berkaitan dengan rasio keuangan yang diukur menggunakan rasio profitabilitas, rasio likuiditas, rasio rasio leverage, dan rasio aktivitas. 
Penentuan kriteria untuk memilih sampel sesuai dengan data penelitian yang dibutuhkan akan dijeaskan seperti tabel dibawah ini.

\section{Penentuan Jumlah Sampel Perusahaan}

\begin{tabular}{|l|c|}
\hline Total Populasi & 27 \\
\hline $\begin{array}{l}\text { Perusahaan yang tidak konsisten terdaftar di Bursa } \\
\text { Efek Indonesia }\end{array}$ & -5 \\
\hline $\begin{array}{l}\text { Perusahaan yang tidak mempublikasikan laporan } \\
\text { keuangan pada periode 2016-2019 }\end{array}$ & -3 \\
\hline $\begin{array}{l}\text { Perusahaan yang tidak mempunyai data lengkap } \\
\text { yang dibutuhkan dalam penelitian }\end{array}$ & -1 \\
\hline Jumlah Sampel & 18 \\
\hline
\end{tabular}

Setelah penentuan sampel yang telah dilakukan, didapatkan 18 Perusahaan Retail yang memenuhi kriteria untuk digunakan sebagai penelitian. Daftar perusahaan yang peneliti gunakan adalah sebagi berikut,
Data Sampel Perusahaan

\begin{tabular}{|c|l|l|}
\hline No & \multicolumn{2}{|c|}{ Nama Perusahaan } \\
\hline 1 & ACES & Ace Hardware Indonesia \\
\hline 2 & AMRT & Sumber Alfaria Trijaya \\
\hline 3 & CENT & Centratama Telekomunikasi Indonesia \\
\hline 4 & CSAP & Catur Sentosa Adiprana \\
\hline 5 & DAYA & Duta Intidaya \\
\hline 6 & ERAA & Erajaya Swasembada \\
\hline 7 & GLOB & Global Teleshop \\
\hline 8 & HERO & Hero Supermarket \\
\hline 9 & KOIN & Kokoh Inti Arebama \\
\hline 10 & LPPF & Matahari Department Store \\
\hline 11 & MAPI & Mitra Adiperkasa \\
\hline 12 & MIDI & Midi Utama Indonesia \\
\hline 13 & MKNT & Mitra Komunikasi Nusantara \\
\hline 14 & MPPA & Matahari Putra Prima \\
\hline 15 & RALS & Ramayana Lestari Sentosa \\
\hline 16 & RANC & Supra Boga Lestari \\
\hline 17 & SONA & Sona Topas Tourism Industry \\
\hline 18 & TELE & Tiphone Mobile Indonesia \\
\hline Sum & Data Diola \\
\hline
\end{tabular}

Sumber: Data Diolah dari BEI

\section{Data dan Jenis Data}

Jenis data yang peneliti gunakan berupa data sekunder. Data sekunder merupakan sumber data penelitian yang diperoleh peneliti secara tidak langsung melalui media perantara yang diambil dari website Bursa Efek Indonesia. Data yang akan digunakan adalah informasi laporan keuangan perusahaan retail pada sektor perdagangan eceran yang terdaftar di Bursa Efek Indonesia (BEI) tahun 2016-2019, data diperoleh dari website www.idx.co.id.

\section{Teknik Pengumpulan Data}

Teknik pengumpulan data yang digunakan dalam penelitian ini adalah dokumentasi, yaitu proses pengumpulan data berupa dokumen atau catatan dari perisitiwa yang lalu dalam bentuk tulisan, gambar, atau karya-karya monumental orang lain (Sugiyono, 2017:240). Dokumentasi ini berupa data laporan keuangan perusahaan retail yang terdaftar di Bursa Efek Indonesia 
(BEI) pada tahun 2016-2019 yang diperoleh di website www.idx.co.id. Data- data tersebut akan diolah menggunakan software SPSS untuk statistik.

\section{Analisis Data}

Analisis data dalam penelitian ini menggunakan statistik deskriptif dan analisis regresi logistik dengan program SPSS. Analisis regresi logistik digunakan dengan tujuan untuk mengetahui probabilitas variabel dependen dapat diprediksi atau dipengaruhi oleh variabel independen. Penelitian ini menggunakan analisis regresi logistik karena memiliki variabel dummy pada variabel dependen, yaitu dengan kategori jika perusahaan mengalami financial distress akan dinilai dengan skala nominal 1, sedangkan perusahaan tidak mengalami financial distress akan dinilai dengan skala nominal 0 .

\section{Hasil dan Pembahasan}

\section{Hasil Statistik Deskriptif}

Statistik deskriptif merupakan metode statistik untuk menggambarkan hasil data yang diteliti. Berikut merupakan penjelasannya.

\begin{tabular}{|l|r|r|r|r|r|}
\hline & D & Minimum & Maximum & Mean & Std. Deviation \\
\hline ROI & 72 & -4.80 & .42 & -.0894 & .64733 \\
CR & 72 & .02 & 8.08 & 1.9296 & 1.78721 \\
DER & 72 & -2.80 & 8.58 & 1.6682 & 1.92329 \\
FAT & 72 & .11 & 28.82 & 2.9249 & 3.82744 \\
FD & 72 & .00 & 1.00 & .2917 & .45772 \\
Valid N (listwise) & 72 & & & & \\
\hline
\end{tabular}

Sumber: Data diolah SPSS versi 16, 2021

Berdasarkan tabel di atas, total sampel yang digunakan adalah 72 perusahaan. Nilai minimum dari variabel rasio profitabilitas (ROI) adalah -4,8 yang mana nilai tersebut terdapat pada perusahaan Global Teleshop. Sedangkan nilai maksimum dari variabel rasio profitabilitas adalah 0,42 yang mana terdapat pada perusahaan Matahari Departemen Store. Nilai rata-rata dari variabel rasio profitabilitas $\left(\mathrm{X}_{1}\right)$ adalah 0,0894 dengan Standar Deviasi 0,64733. Hal ini menunjukkan bahwa rata-rata dari 72 perusahaan retail yang digunakan sebagai sampel dalam penelitian ini memiliki kemungkinan mengalami financial distress sebesar 8\% dari keseluruhan perusahaan memiliki probabilitas mengalami financial distress.

Variabel kedua ialah rasio likuiditas (CR) dengan nilai minimum 0,02 yang mana nilai tersebut terdapat pada Global Teleshop. Sedangkan nilai maksimumnya adalah 8,08 dimana nilai tersebut terdapat pada perusahaan Ace Hardware Indonesia. Nilai rata-rata dari variabel rasio likuiditas $\left(\mathrm{X}_{2}\right)$ adalah 1,9296 dengan Standar Deviasi 1,78721 .

Variabel ketiga ialah rasio leverage (DER) dengan nilai minimum -2,8 yang terdapat pada perusahaan Global Teleshop. Nilai maksimum yang dimiliki variabel ini adalah 8,58 yang mana terdapat pada perusahaan Kokoh Inti Arebama. Nilai rata-rata yang dimiliki adalah 1,7662 sedangkan standar deviasinya bernilai 1,78413 .

Variabel independen terakhir yaitu rasio aktivitas (FAT) memiliki nilai minimum 0,11 yang mana nilai tersebut terdapat pada perusahaan Centratama Telekomunikasi Indonesia. Sedangkan nilai maksimumnya adalah 28,82 yang terdapat pada perusahaan Global Teleshop. Nilai rata-rata variabel rasio aktivitas $\left(\mathrm{X}_{4}\right)$ adalah 2,9249 dengan standar deviasi bernilai 3,82744.

Variabel dependen yaitu financial distress (Y) memiliki nilai minimum 0 dan nilai maksimumnya 1 karena merupakan variabel dummy. Nilai rata-rata variabel ini adalah 0,2917 dengan standar deviasi yang bernilai 0,45772 .

\section{Analisis Regresi Logistik}

Analisis yang digunakan pada penelitian ini adalah analisis regresi logistik dengan penjelasan sebagai berikut.

\section{Ringkasan Jumlah Sampel}

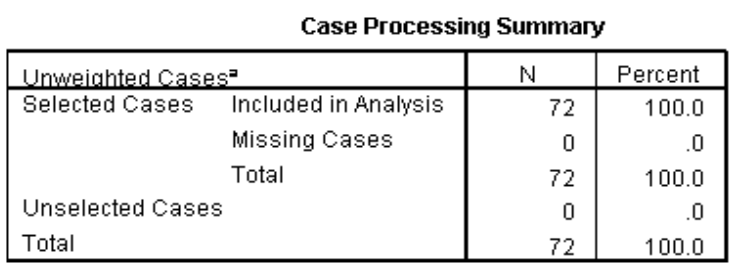

a. If weight is in effect, see classification table for the total number of cases.

Sumber: Data diolah SPSS versi 16, 2021

Kode Variabel Dependen 


\section{Dependent Variable Encoding}

\begin{tabular}{|l|r|}
\hline Original Value & Internal Value \\
\hline non distress & 0 \\
distress & 1 \\
\hline
\end{tabular}

Sumber: Data diolah SPSS versi 16, 2021

Berdasarkan tabel ringkasan jumlah sampel di atas dijelaskan bahwa jumlah sampel yang digunakan pada penelitian ini adalah 72 sampel. Selanjutnya pada tabel kode variabel dependen menjelaskan tentang kode variabel dependen $(\mathrm{Y})$ pada penelitian. Terdapat dua kode kategori variabel dependen yaitu "distress" dengan kode 0 dan "non distress" dengan kode 1. Penyebab referensi tersebut adalah penulis ingin mengetahui jika variabel independen pada penelitian ini dapat memengaruhi variabel dependen dengan dua kode kategori tersebut. Sedangkan variabel independen yang dimaksud antara lain rasio probabilitas $\left(\mathrm{X}_{1}\right)$, rasio likuiditas $\left(\mathrm{X}_{2}\right)$, rasio leverage $\left(\mathrm{X}_{3}\right)$, dan rasio aktivitas $\left(\mathrm{X}_{4}\right)$.

\section{Menilai Keseluruhan Model (Overall Model Fit Test)}

Penilaian ini dilakukan untuk mengetahui model yang dihipotesiskan fit dengan data atau tidak yang menggunakan hasil output dari SPSS versi 16. Terdapat 2 hasil yaitu sebagai berikut.

a. Sebelum variabel independen dimasukkan dalam model.

\section{Iteration History pada Blok 0}

\begin{tabular}{|c|c|c|c|}
\hline \multicolumn{4}{|c|}{ Iteration History ${ }^{3, b}$} \\
\hline \multirow{2}{*}{\multicolumn{2}{|c|}{ Iteration }} & \multirow[b]{2}{*}{$\begin{array}{l}-2 \text { Log } \\
\text { likelihood }\end{array}$} & Coefficients \\
\hline & & & Constant \\
\hline Step 0 & 1 & 86.967 & -.833 \\
\hline & 2 & 86.924 & -.887 \\
\hline & 3 & & -.887 \\
\hline
\end{tabular}

a. Constant is included in the model.

b. Initial -2 Log Likelihood: 86,924

c. Estimation terminated at iteration number 3 because changed by less than ,001.

Sumber: Data diolah SPSS versi 16, 2021

Berdasarkan tabel di atas menjelaskan bahwa tabel iteration history pada block 0 : beginning atau pada saat variabel independen yakni rasio profitabilitas $\left(\mathrm{X}_{1}\right)$, rasio likuiditas $\left(X_{2}\right)$, rasio leverage $\left(X_{3}\right)$, dan rasio aktivitas
$\left(\mathrm{X}_{4}\right)$ tidak dimasukkan dalam model regresi. Nilai -2 Log Likelihood yang didapatkan dengan jumlah sampel 72 ialah 86,924 . Nilai tersebut kemudian dikonsultasikan dengan Chi Square tabel $\left(\mathrm{X}^{2}\right)$ dengan nilai df (Degree of Freedom) yaitu N-1 $=71$ dan probabilitas 0,05 yaitu 91,670. Maka diperoleh nilai $-2 \log$ Likelibood kurang dari Chi Square tabel $\left(\mathrm{X}^{2}\right)$ $(86,924<91,670)$ sehingga Ho diterima. Kesimpulannya yaitu model yang dihipotesiskan fit dengan data.

b. Sesudah variabel independen dimasukkan dalam model.

\section{Iteration History pada Blok 1}

\begin{tabular}{|c|c|c|c|c|c|c|c|}
\hline \multicolumn{8}{|c|}{ Iteration History ${ }^{3, b, c, d}$} \\
\hline \multirow[b]{2}{*}{ Iteration } & & \multirow[b]{2}{*}{$\begin{array}{l}-2 \mathrm{Log} \\
\text { likelihood }\end{array}$} & \multicolumn{5}{|c|}{ Coefficients } \\
\hline & & & Constant & ROI & $C R$ & DER & FAT \\
\hline \multirow[t]{9}{*}{ Step 1} & 1 & 59.398 & -1.145 & -1.060 & -.241 & .370 & .022 \\
\hline & 2 & 45.924 & -1.371 & -2.272 & -.623 & .548 & .099 \\
\hline & 3 & 38.169 & -.788 & -3.751 & -1.389 & 696 & .077 \\
\hline & 4 & 33.416 & .230 & -7.356 & -2.223 & .783 & -.032 \\
\hline & 5 & 31.093 & 1.452 & -12.432 & -3.076 & .812 & -.171 \\
\hline & 6 & 30.677 & 2.078 & -15.394 & -3.635 & .851 & -.226 \\
\hline & 7 & 30.660 & 2.219 & -16.106 & -3.773 & .859 & -.232 \\
\hline & 8 & 30.660 & 2.227 & -16.140 & -3.781 & 859 & -.231 \\
\hline & 9 & 30.660 & 2.227 & -16.141 & -3.781 & .859 & -.231 \\
\hline \multirow{2}{*}{\multicolumn{8}{|c|}{ a. Method: Enter }} \\
\hline & & & & & & & \\
\hline \multicolumn{8}{|c|}{ c. Initial-2 Log Likelihood: 86,924} \\
\hline
\end{tabular}

Sumber: Data diolah SPSS versi 16, 2021

Berdasarkan tabel di atas menjelaskan bahwa tabel iteration bistory pada block 1: Method atau pada saat variabel independen dimasukkan dalam model regresi dengan jumlah sampel 72 mendapatkan nilai -2 Log Likelihood sebesar 30.660. Nilai tersebut kemudian dikonsultasikan dengan Chi Square tabel $\left(\mathrm{X}^{2}\right)$ dengan nilai df (Degree of Freedom) yaitu $\mathrm{N}-1=71$ dan probabilitas 0,05 yaitu 91,670. Maka diperoleh nilai $-2 \quad \log$ Likelihood kurang dari Chi Square tabel $\left(\mathrm{X}^{2}\right)$ $(30,660<91,670)$ sehingga Ho diterima. Kesimpulannya sama dengan Block 0 : Beginning di atas yaitu model yang dihipotesiskan fit dengan data.

Berdasarkan tabel pada blok 0 dan blok 1 diatas, juga dapat disimpulkan bahwa nilai -2LL awal sebesar 86,924 sedangkan nilai 2LL akhir sebesar 30,660. Penurunan nilai 2LL tersebut menunjukkan bahwa model regresi yang diuji dapat dikatakan baik, atau dalam arti model yang dihipotesiskan fit dengan data.

Tabel Klasifikasi 2 × 2 


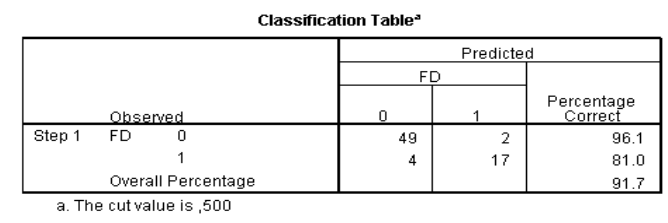

Sumber: Data diolah SPSS versi 16, 2021

Berdasarkan tabel di atas, kekuatan prediksi dari model regresi untuk memprediksi kemungkinan bahwa perusahaan tidak mengalami financial distress yaitu sebesar 96,1\%. Nilai tersebut menunjukkan bahwa dari 51 total observasi yang tidak mengalami financial distress terdapat 49 total observasi diprediksi tidak mengalami financial distress sedangkan 2 total observasi diprediksi mengalami financial distress. Sedangkan kekuatan prediksi dari kemungkinan bahwa perusahaan mengalami financial distress yaitu sebesar $81 \%$. Nilai tersebut menunjukkan bahwa dari 21 total observasi yang mengalami financial distress terdapat 4 total observasi yang diprediksi tidak mengalami financial distress, sedangkan 17 total observasi diprediksi mengalami financial distress.

\section{Koefisien Determinasi (Nagelkerke's $R$ Square)}

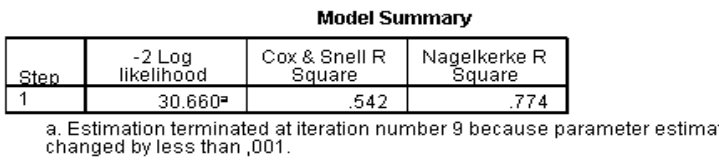

Sumber: Data diolah SPSS versi 16, 2021

Berdasarkan tabel di atas, menjelaskan bahwa Nilai Nagelkerke $R$ Square sebesar 0,774 dan Cox \& Snell R Square sebesar 0,542. Hal tersebut memiliki arti yaitu kemampuan variabel independen dalam menjelaskan variabel dependen sebesar 0,774 atau $77,4 \%$. Sedangkan sisanya sebesar $22,6 \%$ tidak dijelaskan dalam model atau dijelaskan oleh variabel lain yang tidak ada dalam penelitian ini.

\section{Uji Kelayakan Model Regresi}

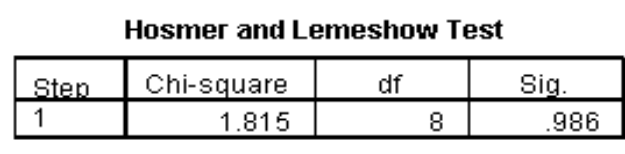

Sumber: Data diolah SPSS versi 16, 2021

Berdasarkan tabel di atas, nilai Chi Square yang didapatkan sebesar 1,815 dengan nilai signifikansi sebesar 0,986 . Berdasarkan hasil pengujian tersebut, nilai signifikansinya lebih besar dari 0,05. Artinya model dapat diterima dan pengujian hipotesis dapat dilakukan karena cocok dengan data yang diobservasi.

\section{Uji Multikolinearitas}

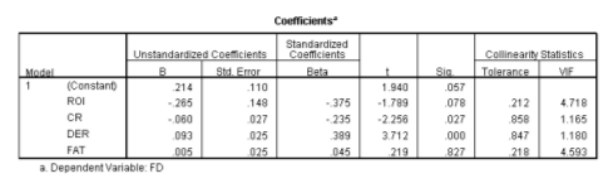

Sumber: Data diolah SPSS versi 16, 2021

Berdasarkan tabel di atas, nilai Variance Inflation Factor (VIF) antar variabel kurang dari 10 yang mana memiliki arti model tidak memuat multikolinearitas.

\section{Uji Hipotesis}

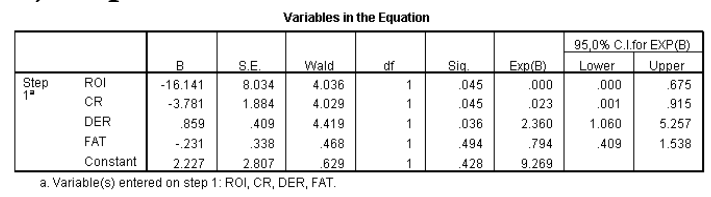

Sumber: Data diolah SPSS versi 16, 2021

Berdasarkan nilai-nilai B pada tabel di atas, maka model persamaan yang dapat dibentuk adalah sebagai berikut:

$$
\begin{aligned}
\mathrm{L} \frac{\mathrm{P}}{1-\mathrm{P}}=2,227- & 16,141 \mathrm{X}_{1}-3.781 \mathrm{X}_{2} \\
+ & 0,859 \mathrm{X}_{3}-0,231 \mathrm{X}_{4}
\end{aligned}
$$

Dimana:

$$
\begin{array}{ll}
\mathrm{L} \frac{\mathrm{P}}{1-\mathrm{P}} & \text { : Financial Distress } \\
\mathrm{X}_{1} & : \text { Rasio Profitabilitas } \\
\mathrm{X}_{2} & : \text { Rasio Likuiditas } \\
\mathrm{X}_{3} & : \text { Rasio leverage } \\
\mathrm{X}_{4} & : \text { Rasio Aktivitas }
\end{array}
$$

Sedangkan untuk penjelasan mengenai nilai konstanta dan koefisien adalah sebagai berikut. 
a. Konstanta sebesar 2,227 berarti bahwa tanpa adanya pengaruh dari seluruh variabel independen $(\mathrm{X})$ maka besarnya financial distress (Y) pada suatu perusahaan adalah 2,227.

b. Koefisien regresi $\mathrm{X}_{1}$ adalah $-16,141$ sehingga setiap penambahan satu satuan rasio profitabilitas $\left(\mathrm{X}_{1}\right)$ akan mengakibatkan penambahan -16,141 financial distress $(\mathrm{Y})$ suatu perusahaan.

c. Koefisien regresi $\mathrm{X}_{2}$ adalah $-3,781$ sehingga setiap penambahan satu satuan rasio likuiditas $\left(\mathrm{X}_{2}\right)$ akan mengakibatkan penambahan -3,781 financial distress $(\mathrm{Y})$ suatu perusahaan.

d. Koefisien regresi $\mathrm{X}_{3}$ adalah 0,859 sehingga setiap penambahan satu satuan rasio leverage $\left(\mathrm{X}_{3}\right)$ akan mengakibatkan penambahan 0,859 financial distress $(\mathrm{Y})$ suatu perusahaan.

e. Koefisien regresi $\mathrm{X}_{4}$ adalah -0,231 sehingga setiap penambahan satu satuan rasio aktivitas $\left(\mathrm{X}_{4}\right)$ akan mengakibatkan penambahan -0,231 financial distress $(\mathrm{Y})$ suatu perusahaan.

\section{Pembahasan \\ Pengaruh Rasio Profitabilitas Terhadap Financial Distress}

Berdasarkan tabel uji hipotesis di atas, menjelaskan bahwa variabel rasio profitabilitas $\left(\mathrm{X}_{1}\right)$ memiliki nilai signifikansi 0,045 . Nilai signifikansi tersebut kurang dari 0,05 sehingga variabel rasio profitabilitas $\left(\mathrm{X}_{1}\right)$ memiliki pengaruh terhadap financial distress (Y). Sedangkan nilai konstanta dari variabel $\mathrm{X}_{1}$ adalah -16,141 yang mana berarti pengaruh rasio profitabilitas $\left(\mathrm{X}_{1}\right)$ terhadap financial distress $(\mathrm{Y})$ suatu perusahaan adalah negatif. Kesimpulan yang dapat diambil adalah H0 ditolak dan $\mathrm{H} 1$ diterima yaitu rasio profitabilitas $\left(\mathrm{X}_{1}\right)$ memiliki pengaruh negatif terhadap financial distress $(\mathrm{Y})$ suatu perusahaan.

Hasil ini sesuai dengan hasil penelitian dari Ni Wayan Agustini \& Ni Gusti Putu Wirawati (2019) dan Firasari Nukmaningtyas \& Saparila Wonokinasih (2018) yang mengatakan bahwa rasio profitabilitas (ROA) berpengaruh negatif terhadap financial distress. Namun hasil penelitian Tri Wulandari (2017) tidak sesuai dengan penelitian ini karena menyatakan bahwa rasio profitabilitas tidak berpengaruh signifikan terhadap financial distress.

Rasio profitabilitas yang tinggi dapat menunjukkan kemampuan perusahaan dalam menggunakan dan mengelola asetnya secara baik untuk menghasilkan laba sehingga dapat mengurangi biaya yang dikeluarkan perusahaan. Oleh sebab itu maka perusahaan akan memperoleh penghematan dana dan memiliki kecukupan dana untuk menjalankan usahanya sehingga terhindar dari kemungkinan financial distress. Begitupun sebaliknya, jika rasio profitabilitas bernilai rendah dapat memungkinkan kurang efektifnya perusahaan dalam mengelola aset yang dimilikinya sehingga dapat menambah biaya ataupun dapat menimbulkan kerugian yang berakibat berkurangnya arus kas sehingga dapat memungkinkan perusahaan mengalami financial distress.

\section{Pengaruh Rasio Likuiditas Terhadap Financial Distress}

Variabel rasio likuiditas $\left(\mathrm{X}_{2}\right)$ memiliki nilai signifikansi 0,023. Dikarenakan nilai signifikansi kurang dari 0,05 maka variabel rasio likuiditas $\left(\mathrm{X}_{2}\right)$ dinyatakan memiliki pengaruh terhadap financial distress (Y). Sedangkan nilai konstanta dari variabel $\mathrm{X}_{2}$ adalah $-3,781$ yang mana berarti pengaruh rasio likuiditas $\left(\mathrm{X}_{2}\right)$ terhadap financial distress (Y) suatu perusahaan adalah negatif. Kesimpulan yang dapat diambil adalah $\mathrm{H0}$ ditolak dan $\mathrm{H} 2$ diterima yaitu rasio likuiditas $\left(\mathrm{X}_{2}\right)$ memiliki pengaruh negatif terhadap financial distress $(\mathrm{Y})$ suatu perusahaan.

Hasil penelitian ini sama dengan penelitian Listyorini Wahyu Widati \& Bayu Adhi Pratama (2018) tentang rasio likuiditas yang diukur dengan Current Ratio (CR) terhadap financial distress mengatakan bahwa rasio likuiditas berpengaruh negatif secara signifikan terhadap financial distress. Sedangkan hasil penelitian Wonokinasih (2018) dan Wulandari (2017) berbeda dengan penelitian ini karena mengatakan bahwa rasio likuiditas tidak berpengaruh secara signifikan terhadap financial distress.

Berpengaruhnya rasio likuiditas dapat disebabkan karena perusahaan retail yang digunakan dalam penelitian ini dapat dikatakan mampu untuk mendanai operasional perusahaan dalam memenuhi kewajiban jangka pendek yang dimilikinya. 
Tingginya nilai rasio likuiditas diakibatkan besarnya nilai aset yang dimiliki perusahaan. Hal ini terbukti bahwa rasio likuiditas berpengaruh negatif terhadap financial distress dalam artian semakin tinggi nilai rasio ini maka akan semakin kecil kemungkinan perusahaan mengalami financial distress.

\section{Pengaruh Rasio leverage Terhadap Financial Distress}

Variabel rasio leverage $\left(\mathrm{X}_{3}\right)$ memiliki nilai signifikansi 0,036. Dikarenakan nilai signifikansi kurang dari 0,05 maka variabel rasio leverage $\left(\mathrm{X}_{3}\right)$ dinyatakan memiliki pengaruh terhadap financial distress $(\mathrm{Y})$. Sedangkan nilai konstanta dari variabel $\mathrm{X}_{2}$ adalah 0,859 yang mana berarti pengaruh rasio leverage $\left(\mathrm{X}_{3}\right)$ terhadap financial distress $(\mathrm{Y})$ suatu perusahaan adalah positif. Kesimpulan yang dapat diambil adalah $\mathrm{H} 0$ ditolak dan $\mathrm{H} 3$ diterima yaitu rasio leverage $\left(\mathrm{X}_{3}\right)$ memiliki pengaruh positif terhadap financial distress $(\mathrm{Y})$ suatu perusahaan.

Hasil penelitian ini berbeda dengan penelitian sama dengan Ni Wayan Agustini \& Ni Gusti Putu Wirawati (2019) tentang rasio leverage yang diukur dengan Debt to Assets Ratio (DAR) terhadap financial distress mengatakan bahwa rasio leverage berpengaruh positif secara signifikan terhadap financial distress. Sedangkan penelitian ini berbeda dengan penelitian yang telah dilakukan oleh Widhiari dan Nukmaningtyas (2018) mengatakan bahwa rasio leverage tidak berpengaruh signifikan terhadap financial distress.

Rasio leverage menunjukkan kemampuan perusahaan dalam membayar seluruh kewajibannya, baik kewajiban jangka pendek maupun kewajiban jangka panjangnya. Semakin besar nilai rasio leverage di suatu perusahaan, maka akan memperbesar kemungkinan perusahaan mengalami financial distress karena perusahaan kesulitan melunasi hutang pokok dan hutang bunga akibat aset yang dimiliki perusahaan tidak dapat menjamin hutang-hutangnya.

\section{Pengaruh Rasio Aktivitas Terhadap Financial Distress}

Variabel yang terakhir adalah rasio aktivitas $\left(\mathrm{X}_{4}\right)$ yang mana memiliki nilai signifikansi 0,494. Dikarenakan nilai signifikansi lebih dari $0,05(0,494>0,05)$ maka variabel rasio aktivitas $\left(\mathrm{X}_{4}\right)$ dinyatakan tidak memiliki pengaruh terhadap financial distress (Y). Sehingga H4 pada penelitian ini juga ditolak. Hal tersebut dikarenakan baik nilai rasio aktivitas perusahaan negatif maupun positif tidak memengaruhi financial distress dari perusahaan tersebut.

Hasil penelitian ini berbeda dengan penelitian yang telah dilakukan oleh $\mathrm{Ni}$ Wayan Agustini dan Ni Gusti Putu Wirawati (2019) yang menyatakan bahwa rasio aktivitas berpengaruh negatif signifikan dalam memprediksi kondisi financial distress, sedangkan penelitian ini sesuai dengan penelitian yang dilakukan oleh Wulandari (2017) menyatakan bahwa rasio aktivitas tidak berpengaruh terhadap financial distress.

\section{A. Kesimpulan}

Berdasarkan hasil dari analisis penelitian maka dapat disimpulkan beberapa hal sebagai berikut.

1. Rasio profitabilitas memiliki pengaruh negatif terhadap financial distress di suatu perusahaan.

2. Rasio likuiditas memiliki pengaruh negatif terhadap financial distress di suatu perusahaan.

3. Rasio rasio leverage memiliki pengaruh positif terhadap financial distress di suatu perusahaan.

4. Rasio Aktivitas tidak memiliki pengaruh terhadap financial distress di suatu perusahaan.

\section{Referensi}

Altman, Edward I. (1968). Financial Ratio, Discriminant Analysis and the Prediction of Corporate Bankecruptcy. The Journal of Finance, Vol. 22 No. 4 Hal 589-609.

Dwijayanti, S Patricia Febrina. (2010). Penyebab, Dampak, dan Prediksi dari Financial Distress serta Solusi untuk Mengatasi Financial Distress. Jurnal Akuntansi Kontemporer, Vol. 2 No. 2 Hal. 191-205.

Hanafi, Mahduh., Abdul, Halim. (2015). Analisis Laporan Keuangan. Edisi. 4. UPP STIM YKPN. Yogyakarta.

Https://https://ekbis.sindonews.com/read/ 
1240472/34/tantangan-berat-bisnisritel- 1505643397 (diakses pada tanggal 15 agustus 2020).

Http:// https://www.idx.co.id/ (diakses pada tanggal 5 Agustus 2020).

Https://www.bps.go.id/pressrelease/2020/0 5/05/1736/ekonomi-indonesiatriwulan-i-2020-tumbuh-2-97persen.html (diakses pada tanggal 5 Agustus 2020).

Ni Made Inten Septiani dan I Made Dana. 2019. Pengaruh Likuiditas, Rasio leverage, dan Kepemilikan Institusional terhadap Financial Distress pada Perusahaan Property dan Real Estate. E-Jurnal: Fakultas Ekonomi dan Bisnis Universitas Udayana (Unud) Bali.

Ni Wayan Agustini dan Ni Gusti Putu Wirawati. 2019. Pengaruh Rasio Keuangan Pada Financial Distress Perusahaan Ritel Yang Terdaftar di Bursa Efek Indonesia (BEI). E-Jurnal: Fakultas Ekonomi dan Bisnis Universitas Udayana (Unud) Bali.

Listyorini Wahyu Widati dan Bayu Adhi Pratama. 2018. Pengaruh Current Ratio, Debt to Equity Ratio, Return on Equity untuk Memprediksi Kondisi Financial Distress pada Perusahaan Manufaktur yang terdapat di Bursa Efek Indonesia. E-Jurnal: Universitas Stikubank Semarang.

Firasari Nukmaningtyas dan Saparila Wonokinasih. 2018. Penggunaan Rasio Profitabilitas, Likuiditas, Rasio leverage, dan Arus Kas untuk Memprediksi Financial Distress. E-Jurnal : Universitas Brawijaya Malang.

Kasmir. (2016). Analisis Laporan Keuangan (Edisi Kedua, Cet. ke-5). Jakarta : Prenadamedia Group.

Munawir, S. 2010. Analisis laporan Kenangan Edisi keempat. Cetakan Kelima Belas. Yogyakarta: Liberty.

Ramadhani, Ayu Suci, dan Niki Lukviarman. 2009. "Perbandingan Analisis Prediksi
Kebangkrutan Menggunakan Model Altman Pertama, Altman Revisi, dan Altman Modifikasi dengan Ukuran dan Umur Perusahaan Sebagai Variabel Penjelas (Studi Pada Perusahaan Manufaktur yang Terdapat di Bursa Efek Indonesia)". Jurnal. Universitas Islam Indonesia.

Rudianto. (2013). Akuntansi Manajemen Informasi untuk pengambilan keputusan strategis. Jakarta: Penerbit Erlangga.

Sugiyono. (2017). Metode Penelitian Kuantitatif Kualitatif dan R\&D. Bandung: Alfabet

Wulandari, Tri. (2017). Pengaruh Rasio Keuangan Terhadap Kondisi Financial Distress. Jurnal Mutiara Akuntansi, Vol. 2, No. 2, 18-32. 